\title{
Könyvszemle
}

SIPOS JÚLIA GONDOZÁSÁBAN

\section{HOLNAPLÁNYOK - PSZICHOANALITIKUS NŐK A BUDAPESTI ISKOLÁBAN}

Borgos Anna könyve a magyar pszichoanalízis női úttöröit mutatja be. A gyakran tragikus, ám lenyügözően érdekes emberi történetek a huszadik század gyorsan pörgő történelmének két ellentmondásos folyamatába ágyazódnak: egyfelől gyilkos háborúk zajlanak, nemzetek és kultúrák omlanak össze, a modern civilizációjára oly büszke fejlett világban alig van ember, akit ne sújtanának közelről veszteségek és tragédiák, másfelől kétségtelen haladás következik be a kultúra és a gazdaság számos, a modernizáció által elindított folyamatában. Ezek közé tartozik a nők társadalmi emancipációja, amelyben az első fontos határátlépések a huszadik század első évtizedeihez kapcsolódnak. Ekkor kezdenek a nők a történelemben először - eleinte lassú ütemben, de visszafordíthatatlanul - olyan területeken tevékenykedni, amelyeken korábban egyértelmü volt a férfiak kizárólagossága.

A Borgos Anna által bemutatott pszichoanalitikusok a fenti kettősséget saját sorsukban is megélték. A 19-20. század fordulóján a közfelfogás szerint a nők gyengébb intellektuális képességekkel és erkölcsi érzékkel rendelkeztek, és miként a szerző a bevezető fejezetben rámutat, Sigmund Freud és az általa teremtett pszichoanalitikus mozgalom tagjainak többsége osztotta ezt a véleményt. Kérdés, hogy jogos-e mindezt számon kérni rajtuk, hiszen a nőkkel kapcsolatos elöítéletek enyhülésének kezdeténél tartunk. Így az is fontos állomás, hogy Freud nem genetikai okokat lát ennek hátterében, hanem a nők a férfiakétól eltérő pszichoszexuális fejlődésének tulajdonítja. Freud konzervatív nézetei a nőkkel kapcsolatban azonban elsősorban elméleti természetủek voltak, mivel - hívja fel Borgos a figyelmet - egyébként támogatta és segítette a nők részvételét a pszichoanalitikus mozgalomban.

A pszichoanalízis olyan területnek bizonyult - írja a szerzö -, amely különösen kedvezett a háztartáson és a gyermeknevelésen túlmutató szerepet kereső nők ambícióinak. A pszichoterápiában fontos szerep jut a hagyományosan „nőiesnek” tekintett tulajdonságoknak: az empátiának és a gondoskodás iránti hajlamnak. A pszichoanalitikussá válásnak Bécsben és Budapesten nem volt feltétele a diploma, amely ebben az időben csak néhány kiválasztott számára volt elérhető. Egy további ok, amely szerepet játszott a pszichoanalitikus nők folyamatosan gyarapodó számában - elemzi Borgos -, hogy az előrejutás sikeresebb lehetett azokon 
a pályákon, amelyek maguk is újak voltak, még nem jött létre bennük a hatalmi pozíciókat megszilárdító belső hierarchia. A női pszichoanalitikusok aránya így folyamatosan nő, az 1930-as évekre már nemzetközivé váló egyesület tagságában eléri a 30\%-ot. A magyar pszichoanalitikus egyesületben még ennél is kedvezőbb az arány: csaknem ugyanannyi nő, mint férfi a tagja.

A kötetben a társadalmi-történeti háttér felvázolását követi a női emancipáció e korai képviselőinek a két háborúba, üldözésbe, válságokba ágyazódott élettörténete. A hazai pszichoanalitikus nők túlnyomó többsége művelt zsidó polgári családból származik: olyan környezetből, amelyben „A társadalmi mobilitás egyszerre képesség, lehetőség és kényszer is" (49.). Nehéz sorsuk sem tudta megakadályozni őket választott szakmájuk magas szintủ mủvelésében. Borgos Anna hatalmas mennyiségủ anyagot gyüjtött össze, az archív anyagokon, dokumentumokon kívül személyes interjúk képezik az öt részletes és a huszonhét rövidebb életrajz forrásait (a kötet utolsó lábjegyzete a 663. számot viseli). Munkájának különleges jelentőséget ad, hogy a vége felé jár az az idő, amikor még fellelhetőek a bemutatott analitikusokkal személyes kapcsolatban állók, gyermekeik, unokáik, tanítványaik. Egy sor, korábban ismeretlen fénykép is illusztrálja a „holnaplányok" (a különlegesen tragikus sorsú Gimesné Hajdu Lilly nevezte így önmagát és a hozzá hasonló törekvésekkel rendelkezőket) szakmájukért, a teljesebb életért vívott küzdelmeit. Borgos feltáró munkáját megismerve különösen fájó gondolat, mennyivel többre lettek volna képesek ezek a tehetséges, eredeti gondolkodású emberek nyugalmasabb feltételek között.

A könyv nagyobbik felét az élettörténetek teszik ki, amelyekről vagy számos részletükről most olvashat először az érdeklődő. Az 1891-ben született Hajdu Lilly (később Gimesné) sorsa mintegy egyesíti a bemutatott élettörténetek jellegzetességeit. Az orvosegyetemre járó nők legkorábbi nemzedékéhez tartozik. Férjének, a szintén orvos Gimes Miklósnak, a Galilei Kör titkárának írott levelében amiatt aggódik, hogy nem rendelkezik eléggé a nőktől elvárt tulajdonságokkal, az odaadás és a simulékonyság képességével. A korszakban nem mindennapos, hogy férjes asszonyként is folytatja hivatását, mentális betegekkel, értelmi fogyatékosokkal foglalkozik, az 1930-as években válik kiképzett analitikussá. Az erősödő antiszemitizmus elől emigrálni próbálna családjával, de nem sikerül, férje elpusztul a deportálás következtében, ő azonban két felnőtt gyermekével túléli a második világháborút. Hajdu Lilly és kollégái elkötelezett baloldaliságuk ellenére sem képesek a pszichoanalízist megvédeni: a sztálinista rezsim számára nem létezik lélektan, sem lelki problémák. Szaktudását valamilyen módon mégis elismerik: az 1950-es években a néhány éve bezárt országos elmegyógyintézet, a „Lipótmező" igazgatója lesz. A volt kolléga, szintén ismert pszichoanalitikus, Paneth Gábor beszámolója alapján mutatja be Borgos azt a kettősséget, amelyben a Hajdu Lillyhez hasonló szakembereknek élnie kellett: abban a tudatban kellett baloldali elkötelezettségüket megörizniük, hogy a politika dogmatikusan elzárkózott meg- 
határozott tudományterületektől, és kényszerhallgatásra ítélte képviselőit is (84.). Hajdu Lilly sorsának drámai végkifejlete ismert: miután fiát, Gimes Miklóst kivégezték a Nagy Imre-perben, az idős anyát pedig érthetetlen gonoszsággal nem engedték külföldön élő családtagjaihoz utazni, öngyilkosságot követett el.

A magyar pszichoanalitikus nők másik ismert alakja a József Attila analitikusaként emlegetett Gyömrői Edit három ízben kényszerült emigrációra - kétszer Budapestről és egyszer Berlinből -, így megmenekült a zsidóüldözéstől és a baloldali diktatúrától. A regényes életutat elemző módon bemutató Borgos arra hívja fel a figyelmet, hogy a sokféle kulturális váltás nem volt minden szempontból idegen Gyömrői lázadó, a függőséget elutasító természetétől, és miközben szinte az egész világot bejárta, nem vesztette el választott identitását, megőrizte a kontrollt saját élete fölött. A korai útkeresés nehézségeit jeleníti meg a tragikusan fiatalon elhunyt, különlegesen eredeti gondolkodó, Bálint Alice élettörténete. Az egyik első női analitikus, Ferenczi-tanítvány és Freud-fordító, Kovács Vilma lánya eredetileg matematikusnak készült, de végzett politikatudományi, sőt földrajzi tanulmányokat is. Édesanyja, Kovács Vilma élettörténetéről szintén fontos részleteket tárt fel a szerző, részben a Bálint család közelmúltban kutathatóvá vált naplói és személyes feljegyzései alapján. Kovács Vilma személyiségében egyesítette az adott korban bátornak, extravagánsnak számító, független nő szerepét az empatikus, támogató szereppel, amely mind analitikusi, mind társasági habitusát jellemezte.

A szerző felkutatta számos kevésbé ismert, de a pszichoanalitikus közéletben, a pszichoanalízis népszerüsítésében szerepet játszó női szakember élettörténetét is. A számukra adatott rövid időben, a két világháború között konferenciákat szerveztek, folyóiratokat müködtettek, egyéni terápiát és kiképzést végeztek. Voltak, akik áldozatul estek a háború borzalmainak, mások menekülésre kényszerültek: kevesen tudnak ma már Margaret Mahler (eredetileg Schönberger Margit) vagy Therese Benedek (Friedmann Teréz) magyar gyökereiről. Az itthon maradottak rosszabbul jártak: évtizedeken át politikai okokból kényszerültek rejtőzködésre. Ám a pszichoanalitikus mozgalomban formálódó szakmai felfogás, a humanizmus és a megértés alakította nézeteik tovább éltek, Rotter Lilián, Hermann Alice, Liebermann Lucy és mások pszichológusok és pedagógusok nemzedékeire voltak hatással.

Borgos Anna könyve nemcsak a pszichológusok érdeklődésére tarthat számot, haszonnal forgathatják a huszadik század társadalom- és kultúrtörténetének tanulmányozói is.

(Borgos Anna: Holnaplányok. Nök a pszichoanalízis budapesti iskolájában Budapest: Noran Libro, 2018)

Vajda Zsuzsanna pszichológus 